\title{
PRRT2 wt Allele
}

National Cancer Institute

\section{Source}

National Cancer Institute. PRRT 2 wt Allele. NCI Thesaurus. Code C101621.

Human PRRT 2 wild-type allele is located in the vicinity of $16 p 11.2$ and is approximately 4 $\mathrm{kb}$ in length. This allele, which encodes proline-rich transmembrane protein 2, may be involved in the development of the brain and spinal cord. Mutation of the gene is associated with both episodic kinesigenic dyskinesia-1 and infantile convulsion and choreoathetosis syndrome. 